\title{
The genus Eryma Meyer, 1840 (Crustacea: Decapoda: Erymidae): new synonyms, systematic and stratigraphic implications
}

\author{
Julien Devillez $^{1,2,{ }^{*}}$ and Sylvain Charbonnier ${ }^{1,2}$ \\ ${ }^{1}$ Muséum national d'Histoire naturelle, Paris, France \\ ${ }^{2}$ Centre de recherche sur la Paléobiodiversité et les Paléoenvironnements, CR2P, UMR 7207, Sorbonne Universités, MNHN, UPMC, \\ CNRS, 57, rue Cuvier, 75005 Paris, France
}

\begin{abstract}
Among Erymidae Van Straelen, 1925 (Van Straelen V. 1925. Contribution à l'étude des crustacés décapodes de la période jurassique. Mémoires de la Classe des Sciences de l'Académie royale de Belgique 7: 1-462), typical Mesozoic crustaceans, the genus Eryma Meyer, 1840 (Meyer H. von. 1840a. Briefliche Mittheilungen. Neues Jahrbuch für Mineralogie, Geognosie, Geologie und Petrefactenkunde 576-587) includes the largest number of species, mainly from Jurassic deposits. However, the lack of clear diagnoses for erymid genera has led to mistakes in generic assignments and to the establishment of redundant genera. The review of the concept of Eryma herein presents an attempt to clarify its diagnosis, mainly supported by the carapace groove pattern and the morphology of chelae of the first pair of pereiopods, and to emphasize its systematic implications. Thus, we maintain the synonymy of Klytia Meyer, 1840, Bolina Münster, 1839 (Münster G. 1839. Decapoda Macrura. Abbildung und Beschreibung der Fossilen Langschwänzigen Krebse in den Kalkschiefern von Bayern. Beiträge zur Petrefaktenkunde 2: 1-88) (sensu Étallon [Étallon A. 1859. Description des crustacés fossiles de la Haute-Saône et du Haut-Jura. Bulletin de la Société géologique de France 16: 169-205]), and Erymastacus Beurlen, 1928 (Beurlen K. 1928. Die Decapoden des Schwäbischen Jura mit Ausnahme der aus den oberjurassischen Plattenkalken stammenden. Palaeontographica 70: 115-278) with Eryma. Moreover, a review of the genera Protoclytiopsis Birshtein, 1958 (Birshtein JA. 1958. Ein Vertreter der ältesten Ordo der Crustacea Decapoda Protoclitiopsis antiqua gen. nov. sp. nov. aus dem Permo West-Sibiriens. Doklady Akademii Nauk, SSSR 122: 477-480), and Galicia Garassino and Krobicki, 2002 (Garassino A, Krobicki M. 2002. Galicia marianae n. gen., n. sp. (Crustacea, Decapoda, Astacidea) from the Oxfordian (Upper Jurassic) of the Southern Polish Uplands. Bulletin of the Mizunami Fossil Museum 29: 51-59), reveals the presence of a junction between the postcervical and branchiocardiac grooves. This feature is diagnostic of Eryma and supports the integration of these genera into the synonymy of Eryma. The addition of Protoclytiopsis to the synonymy of Eryma makes Eryma antiquum (Birshtein, 1958) nov. comb. the oldest representative of the genus and of the family, extending its stratigraphic range to the Late Permian (Changhsingian). Thus, this work also emphasizes that Erymidae crossed the Permian-Triassic boundary.
\end{abstract}

Keywords: lobsters / Mesozoic / new synonyms / Permian / Poland / Russia

Résumé - Le genre Eryma Meyer, 1840 (Crustacea: Decapoda: Erymidae) : nouveaux synonymes, implications systématique et stratigraphique. Parmi les Erymidae Van Straelen, 1925 (Van Straelen V. 1925. Contribution à l'étude des crustacés décapodes de la période jurassique. Mémoires de la Classe des Sciences de l'Académie royale de Belgique 7: 1-462), crustacés typiques du Mésozoïque, Eryma Meyer, 1840 (Meyer H. von. 1840a. Briefliche Mittheilungen. Neues Jahrbuch für Mineralogie, Geognosie, Geologie und Petrefactenkunde 576-587) est le genre regroupant le plus grand nombre d'espèces principalement dans les dépôts jurassiques. Cependant, le manque de clarté des diagnoses des genres d'Erymidae a mené à des erreurs dans les identifications génériques ainsi qu'à l'instauration de genres redondants. La révision du concept du genre Eryma présentée ici est donc l'occasion de proposer une diagnose clarifiée, reposant essentiellement sur l'architecture des sillons de la carapace et la

\footnotetext{
* Corresponding author: jdeville@edu.mnhn.fr
} 
morphologie des pinces de la première paire de péréiopodes, et d'en souligner les implications systématiques. Ainsi, la mise en synonymie avec Eryma des genres Klytia Meyer, 1840, Bolina Münster, 1839 (Münster G. 1839. Decapoda Macrura. Abbildung und Beschreibung der Fossilen Langschwänzigen Krebse in den Kalkschiefern von Bayern. Beiträge zur Petrefaktenkunde 2: 1-88) (sensu Étallon [Étallon A. 1859. Description des crustacés fossiles de la Haute-Saône et du Haut-Jura. Bulletin de la Société géologique de France 16: 169-205]) et Erymastacus Beurlen, 1928 (Beurlen K. 1928. Die Decapoden des Schwäbischen Jura mit Ausnahme der aus den oberjurassischen Plattenkalken stammenden. Palaeontographica 70: 115-278) est ici confirmée. De plus, la révision des genres Protoclytiopsis Birshtein, 1958 et Galicia Garassino and Krobicki, 2002 (Garassino A, Krobicki M. 2002. Galicia marianae n. gen., n. sp. (Crustacea, Decapoda, Astacidea) from the Oxfordian (Upper Jurassic) of the Southern Polish Uplands. Bulletin of the Mizunami Fossil Museum 29: 51-59) révèle la présence d'une jonction entre les sillons postcervical et branchiocardiaque. Ce caractère diagnostique d'Eryma justifie l'intégration de ces deux genres dans la synonymie d'Eryma. L'ajout de Protoclytiopsis à la synonymie d'Eryma fait d'Eryma antiquum (Birshtein, 1958) nov. comb. le plus ancien représentant du genre et de la famille, repoussant son extension stratigraphique à la fin du Permien (Changhsingien). Ainsi, ce travail met en lumière le fait que les Erymidae ont franchi la limite Permien-Trias.

Mots clés : homards / Mésozoïque / nouveaux synonymes / Permien / Pologne / Russie

\section{Introduction}

Eryma Meyer, 1840 is a genus of typical Mesozoic crustaceans. It is known by many fossils supporting the greatest number of described species among Erymidae Van Straelen, 1925 (Schweitzer et al., 2010; Hyžný et al., 2015). Eryma is well known in European Jurassic and Early Cretaceous deposits (Carter, 1886; Étallon, 1859, 1861; Oppel, 1861, 1862; Ferry, 1865; Krause, 1891; Lahusen, 1894; Harbort, 1905; Van Straelen, 1920, 1925; Hée, 1924; Beurlen, 1928; Woods, 1925-1931; Birshtein, 1956; Förster, 1965, 1966; Martill, 1991; Garassino, 1996; Schweigert et al., 2000; Fischer, 2003; Etter, 2004; Carpentier et al., 2006; Garassino and Schweigert, 2006; Charbonnier, 2009; Schweitzer et al., 2009; Charbonnier et al., 2010, 2012, 2014, in press; Bravi et al., 2014; Devillez et al., 2016), and some occurrences are also reported throughout the world: in Middle East (Roger, 1946; Förster and Seyed-Emani, 1982; Garassino, 1994), in Africa (Beurlen, 1933; Secrétan, 1984), in North America (Rathbun, 1923, 1926; Feldmann and Titus, 2006) in Latin America (Aguirre-Urreta and Ramos, 1981; Aguirre-Urreta, 1989; J. Luque, pers. com.), in Antarctic (Taylor, 1979) and in Japan (Karasawa et al., 2008; Kato et al., 2010; Devillez et al., 2016).

Currently, the carapace groove pattern of erymid lobsters is the main feature used for genera and species distinction (Van Straelen, 1925; Förster, 1966; Glaessner, 1969). However, the lack of clear generic diagnoses in the works of the nineteenth century and the different states of preservations of crustaceans has led to confusions about the concept of Eryma, and descriptions of redundant genera as consequences (Bolina Münster, 1839, Eryma and Klytia Meyer, 1840 sensu Étallon [1859]). Such confusions persist nowadays but some recent works have attempted to bring clear elements for erymid lobsters discrimination (Hyžný et al., 2015; Devillez et al., 2016).

This work aims to clarify the concept of Eryma on the basis of the carapace groove pattern and the morphology of the first pereiopod chelae. It also emphasizes systematic and stratigraphic implications of such clarification.

\section{Material and methods}

The studied material includes 42 specimens from the palaeontological collections of European institutions (Tab. 1). Except fossils from the Solnhofen Lithographic Limestones, most of the studied specimens are fragmentary with only isolated carapaces or chelae preserved. They were mostly studied using a CETI Belgium MEDO binocular microscope. Line drawings were prepared by the first author.

\section{Systematic palaeontology}

MALACOSTRACA Latreille, 1802

DECAPODA Latreille, 1802

ERYMIDA sensu Schram and Dixon, 2004

Superfamily ERYMOIDEA Van Straelen, 1925

Family ERYMIDAE Van Straelen, 1925

Preliminary remark. - Throughout the literature Erymidae has been included within Astacidea Latreille, 1802 (Van Straelen, 1925; Glaessner, 1969; Aguirre-Urreta, 1989; Schweigert et al., 2000; Garassino and Krobicki, 2002; Crônier and Courville, 2004; Feldmann and Titus, 2006; Garassino and Schweigert, 2006; Schweigert, 2013; Charbonnier et al., 2013), or within Glypheidea Zittel, 1885 (De Grave et al., 2009; Schweitzer et al., 2010; Wahle et al., 2012; Karasawa et al., 2013; Feldmann et al., 2015). Recent phylogenetic analysis of Charbonnier et al. (2015) questioned the assignment of Erymidae to Glypheidea. Then, following Hyžný et al. (2015), we consider the systematic position of the Erymidae as uncertain and do not list the taxonomic rank beyond the superfamily. Hence, following Schram and Dixon (2004), we only include the Erymidae in a separate clade, Erymida.

Genus Eryma Meyer, 1840

(Fig. 1A-C)

Eryma Meyer, 1840: 587.

Klytia Meyer, 1840: 19.

Bolina Münster, 1839 sensu Étallon (1859: 192) (non Mertens, 1833). 
Table 1. List of the examined material.

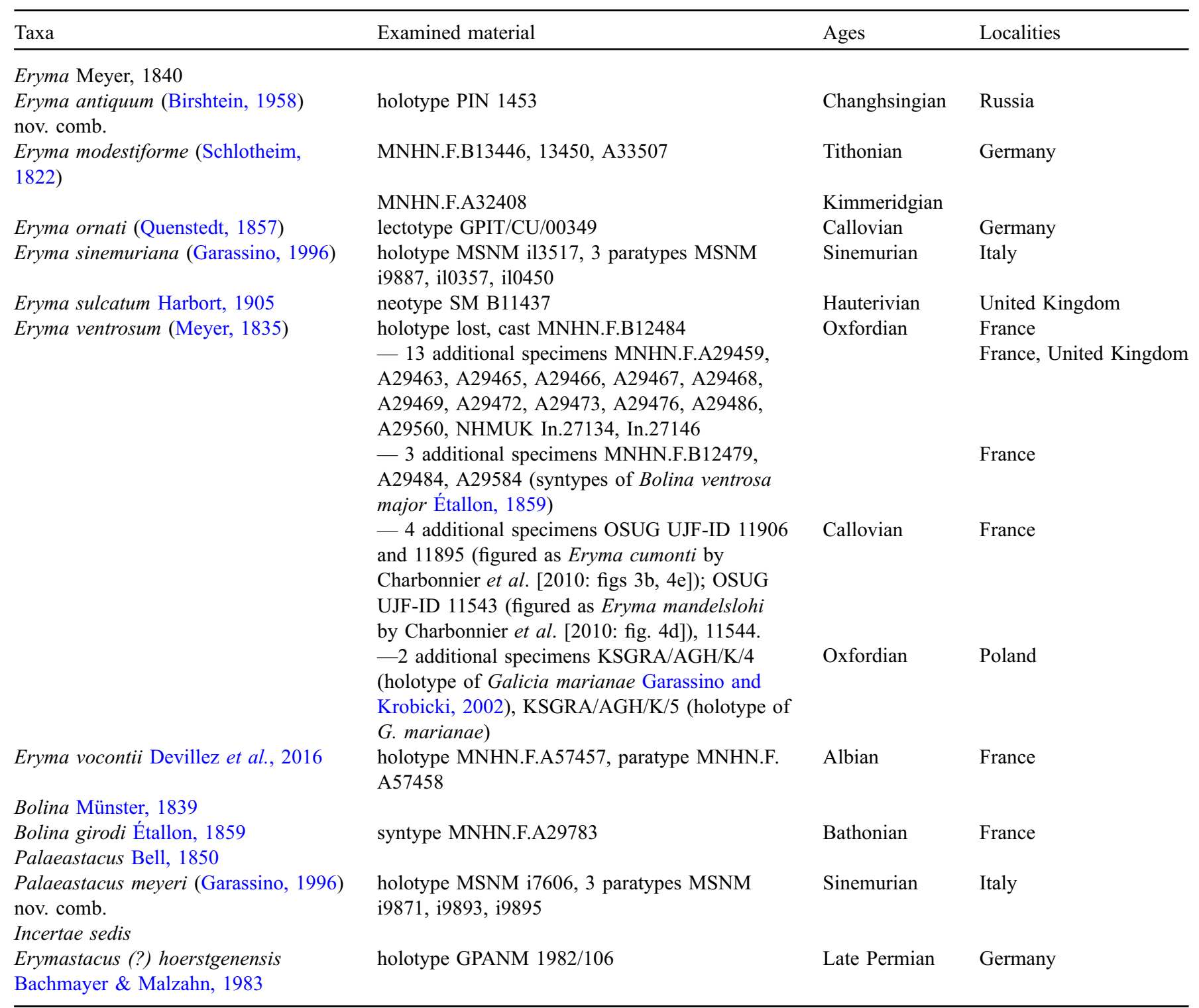

Protoclytiopsis Birshtein, 1958: 477. nov. syn.

Galicia Garassino and Krobicki, 2002: 55. nov. syn.

Eryma - Oppel (1862: 20). - Zittel (1885: 693). Méchin (1901: 74). - Van Straelen (1925: 233). - Rathbun (1926: 127). - Secrétan (1964: 61). - Förster (1966: 88). Glaessner (1969: R455). - Aguirre-Urreta and Ramos (1981: 609). - Secrétan (1984: 516). - Aguirre-Urreta (1989: 513). - Crônier and Courville (2004: 1004). - Feldmann and Titus (2006: 63). - Feldmann and Haggart (2007: 1792). - Hyžný et al. (2015: 375). - Feldmann et al. (2015: 1).

Clytia - Beurlen (1928: 165).

Protoclytiopsis - Förster (1966: 86). - Feldmann et al. (2015: 10).

Klytia - Glaessner (1969: R456).

Galicia - Feldmann et al. (2015: 3).

Type species.-Macrourites modestiformis Schlotheim, 1822, by subsequent designation of Glaessner (1929).
Included species. - A list of fossil species of Eryma, including 60 species, has been done by Schweitzer et al. (2010). However, this work is a compilation, and the species of Eryma need a careful review as suggested by Bravi et al. (2014) and Hyžný et al. (2015). Such review requires the examination of the type material of all included species, so the proposition of a new list is beyond the aims of the present contribution.

Emended diagnosis.-Fusiform intercalated plate; deep cervical groove, joined to dorsal margin and to antennal groove; short gastro-orbital groove originating as a slight median inflexion of cervical groove; postcervical groove joined medially to branchiocardiac groove; branchiocardiac groove strongly inclined, joined to hepatic groove; concavoconvex hepatic groove, joined to cervical groove; inferior groove convex posteriorly, joined to hepatic groove and to ventral margin; inflated $\omega$ area; cephalic region with two divergent rows of tubercles: orbital row with strong distal spine 


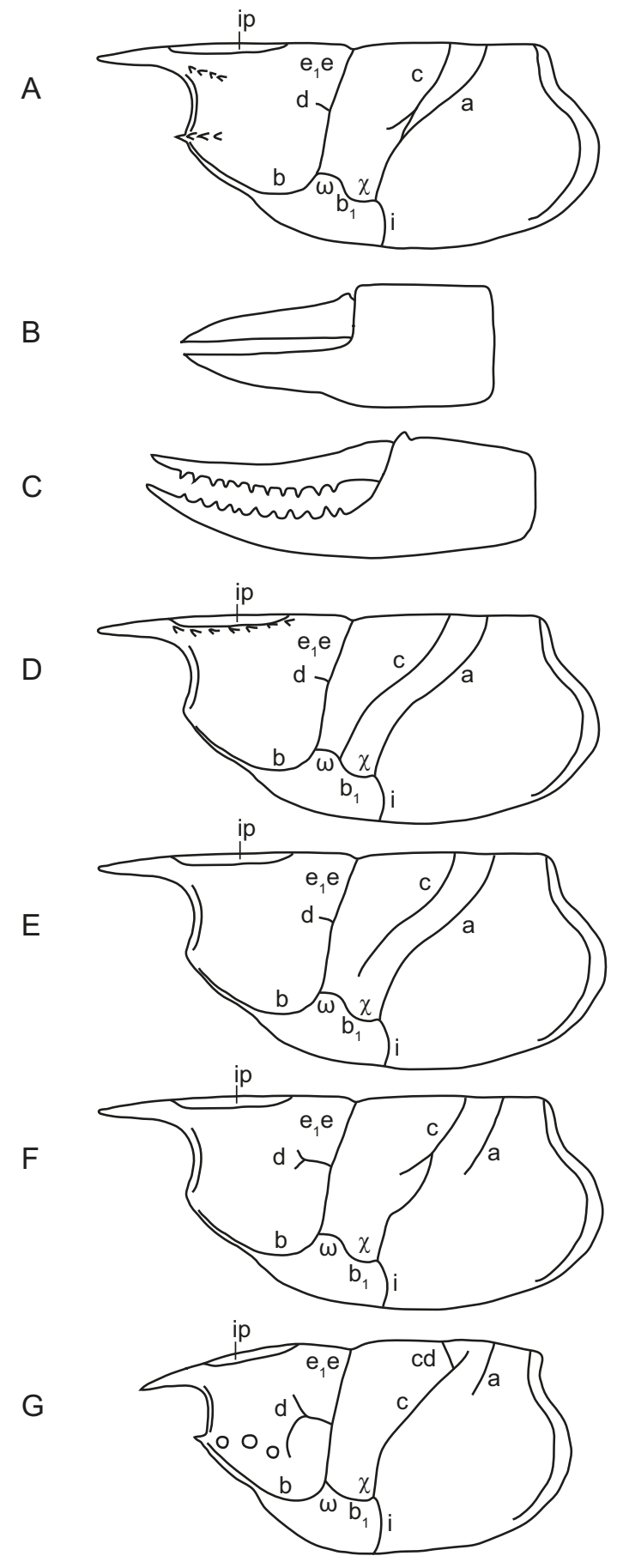

Fig. 1. Line drawings of carapaces and $\mathrm{P} 1$ chelae of erymid lobsters. A-C, Eryma Meyer, 1840: carapace (A), P1 chela form I (B), P1 chela form II (C); D, carapace of Palaeastacus Bell, 1850; E, carapace of Stenodactylina Beurlen, 1928; F, carapace of Enoploclytia M'Coy, 1849; G, carapace of Pustulina Quenstedt, 1857. Abbreviations: a: branchiocardiac groove; b: antennal groove; $\mathrm{b}_{1}$ : hepatic groove; $\mathrm{c}$ : postcervical groove; cd: cardiac groove; $\mathrm{d}$ : gastro-orbital groove; $\mathrm{e}_{1} \mathrm{e}$ : cervical groove; i: inferior groove; ip: intercalated plate; $\omega$ : attachment site of mandibular muscle; $\chi$ : attachment site of adductor testis muscle. Line drawings: J. Devillez and S. Charbonnier. and antennal row with strong distal antennal spine; chelate P1-P3; P1 chelipeds without prominent spines and with homogeneous ornamentation; P1 propodus dorso-ventrally compressed with narrow inner and outer margins; P1 with narrow dactylar bulge; fingers longer than $\mathrm{P} 1$ propodus, equal in length, narrowing gradually to distal extremity; index wider than dactylus (modified after Devillez et al., 2016).

Comments. - According to Hyžný et al. (2015), followed by Devillez et al. (2016), we distinguish two forms of P1 chelae: form I (Fig. 1B) with short rectangular propodus and straight fingers, slightly longer than the propodus; form II (Fig. 1C) with an elongate sub-rectangular or trapezoidal propodus bearing elongated fingers, usually curved inward.

The most recent diagnoses of Eryma proposed by Feldmann and Titus (2006), Hyžný et al. (2015) and Feldmann et al. (2015) are relatively broad, particularly about the characteristics of the groove pattern. So, among the erymid lobsters, Eryma is the only genus exhibiting a junction between postcervical and branchiocardiac grooves. Other erymids such as Enoploclytia M'Coy, 1849 (Fig. 1F) and Pustulina Quenstedt, 1857 (Fig. 1G) show a reduced branchiocardiac groove only joined to dorsal margin, while it is well-developed and joined to the posterior extremity of the hepatic groove in Palaeastacus Bell, 1850 (Fig. 1D) and Stenodactylina Beurlen, 1928 (Fig. 1E) (Devillez et al., 2016).

Discussion. - Meyer (1840) established two genera: (1) Eryma for small crustaceans from the Solnhofen Lithographic Limestones, previously assigned to Glyphea Meyer, 1835 by Münster (1839) (Fig. 2A), and (2) Klytia with Klytia ventrosa (Meyer, 1835) (Oxfordian, Haute-Saône, France) (Fig. 2C-D), and Klytia mandelslohi Meyer, 1840 (Oxfordian, BadenWürttemberg, Germany). According to Étallon (1859), the different states of preservation between the strongly compressed fossils from Solnhofen and the three-dimensionally preserved ones from Haute-Saône and Baden-Württemberg probably prevented Meyer (1840b) to assign them to the same genus. However, Klytia was clearly established based on the junction between postcervical and branchiocardiac grooves (see Meyer [1840b: 20]), which supports the synonymy between Eryma and Klytia. This synonymy was followed by numerous subsequent authors (e.g., Oppel, 1862; Van Straelen, 1925; Förster, 1966) even if some authors maintained the distinction between the two genera (e.g., Beurlen, 1928; Glaessner, 1929). After some hesitation, Glaessner (1969: R626) re-established the synonymy, which has been commonly accepted since then.

Münster (1839) erected Bolina with two new species from the Solnhofen Lithographic Limestones: Bolina pustulosa and Bolina angusta. Later, Etallon (1859) proposed an emended description for Bolina. He described the groove pattern as follows: there are three oblique, wide and deep transverse grooves; the first (cervical groove) is inflected forward and the two others (postcervical and branchiocardiac grooves) are dorsally close, joining each other at carapace mid-height. The carapace groove pattern of Bolina sensu Étallon (1859) clearly fits the diagnosis of Eryma and does not fit the descriptions of Bolina pustulosa and Bolina angusta, which are clearly not erymid lobsters. Moreover, Oppel (1861) proposed the new genera Stenochirus (type species: Bolina angusta) and Pseudastacus (type species: Bolina pustulosa) and remarked that Bolina Münster, 1839 was preoccupied by Bolina Mertens, 1833 (Cnidaria). 

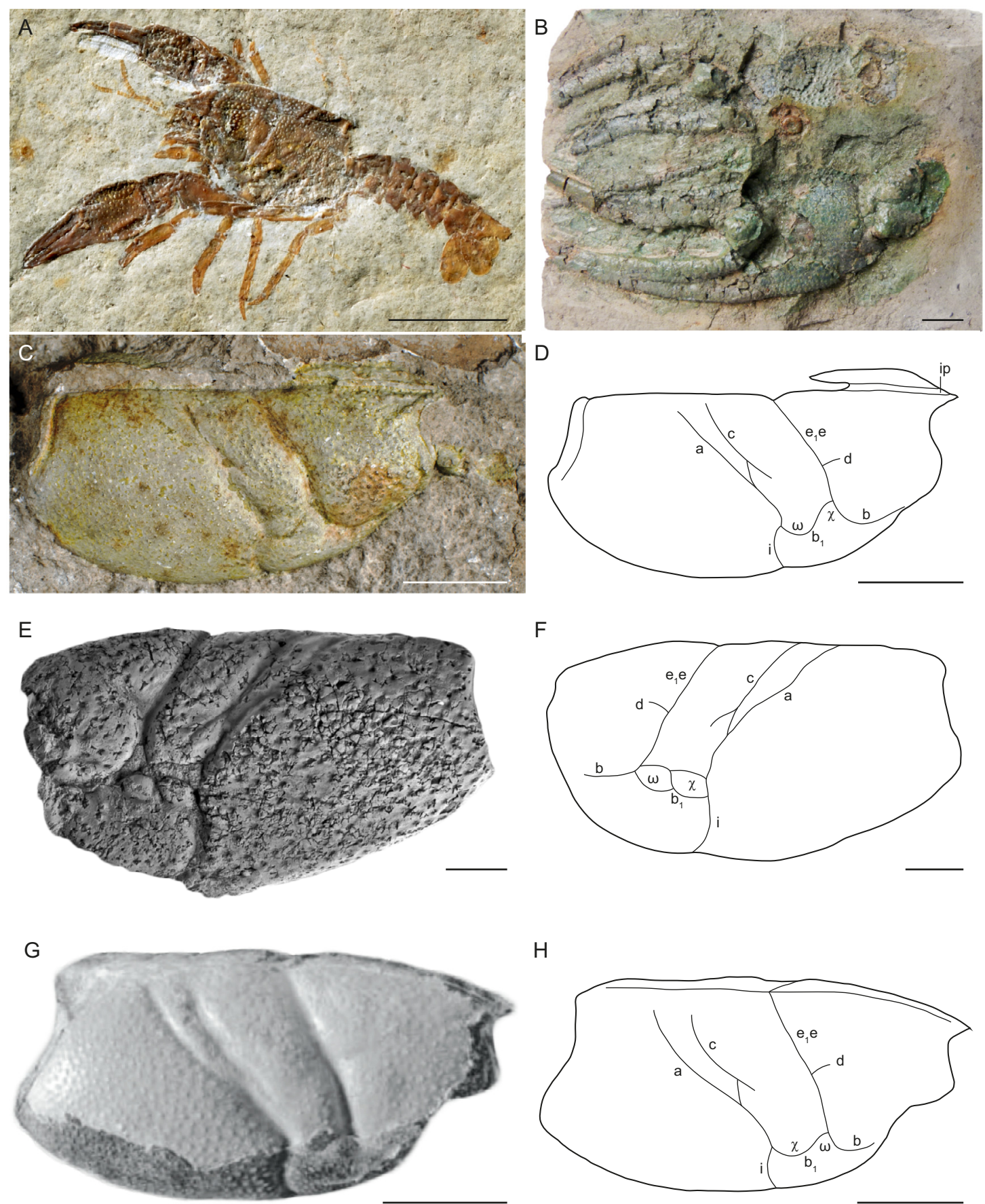

$\mathrm{H}$

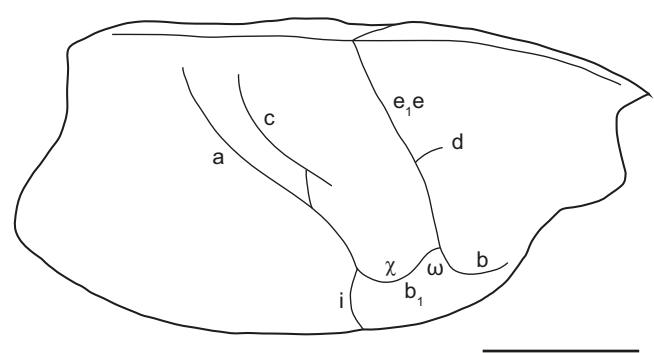

Fig. 2. Eryma representatives from Late Permian and Jurassic. A, specimen MNHN.F.B13450 of Eryma modestiforme (Schlotheim, 1822) from the Tithonian of Solnhofen, Germany; B, P1 chelae of the lectotype GPIT/CU/00349 (Quenstedt coll.) of Eryma ornatum (Quenstedt, 1857) from the Callovian of Gammelshausen, Germany ; C-D, cast of the holotype MNHN.B.12484 of Eryma ventrosum (Meyer, 1840) from the Oxfordian of Calmoutier, France: carapace (C) and line drawing (D); E-F, holotype PIN 1453 of Protoclytiopsis antiqua Birshtein, 1958 from the Changhsingian of Ust-Jenisseisk, Russia: carapace (E) and line drawing (F); G-H, holotype KSGR/AGH/K/4 of Galicia marianae Garassino and Krobicki, 2002 from the Oxfordian of Rudno, Poland: carapace (after Garassino and Krobicki: fig. 7) (C) and line drawing (D). Abbreviations: $a$ : branchiocardiac groove; $b$ : antennal groove; $b_{1}$ : hepatic groove; $c$ : postcervical groove; d: gastro-orbital groove; $\mathrm{e}_{1} \mathrm{e}$ : cervical groove; i: inferior groove; ip: intercalated plate; $\omega$ : attachment site of mandibular muscle; $\chi$ : attachment site of adductor testis muscle. Scale bars $=10$ mm. Photographs: L. Cazes (A), G. Schweigert (B), J. Devillez (C), F. Schram (E). Line drawing: J. Devillez. 
Beurlen (1928) established the genus Erymastacus to accommodate erymid lobsters only known by P1 chelae bearing very long fingers, and previously assigned to Eryma. Later, Glaessner (1929) subsequently designated Glyphea ornati Quenstedt, 1857 as type species for Erymastacus. Throughout the literature this genus was regarded as a junior synonym of Eryma (Förster, 1966; Glaessner, 1969; Schweitzer et al., 2010; Feldmann et al., 2015) or as a distinct genus (Secrétan, 1964; Schweigert et al., 2000; Schweigert and Garassino, 2003; Hyžný et al., 2015). Careful examination of the lectotype of Glyphea ornati (Fig. 2B) leads us to regard it as P1 chelae of Eryma, belonging to form II because of the trapezoidal shaped propodus, the inward curvature of fingers and the index width greater than that of dactylus. In conclusion, we agree with Förster (1966), Glaessner (1969), Schweitzer et al. (2010), Feldmann et al. (2015) and Devillez et al. (2016), by maintaining the synonymy between Erymastacus and Eryma.

Birshtein (1958) erected the new genus Protoclytiopsis with Protoclytiopsis antiqua (Changhsingian, Siberia, Russia) as the type species. This species is known by a single laterally crushed carapace. Förster (1966) pointed out the close similarity between the carapace groove pattern of this species and that of Eryma spp. Finally, he included Protoclytiopsis within the subfamily Eryminae Beurlen, 1928. Förster's opinion was followed by Glaessner (1969) but not by Karasawa et al. (2013), Feldmann et al. (2012) and Feldmann et al. (2015), who assigned Protoclytiopsis within the family Clytiopsidae Beurlen, 1927 (pro Clytiopsinae Beurlen, 1927, which was elevated to family rank by Amati et al. [2004]).

Our examination of the photograph of the holotype of Protoclytiopsis antiqua reveals the presence of the typical grooves of the Erymidae: deep cervical groove, gastro-orbital groove present, postcervical and branchiocardiac grooves almost parallel. Moreover, the postcervical and branchiocardiac grooves are joined medially, as in Eryma (Fig. 2E-F). In conclusion, we consider Protoclytiopsis as a junior synonym of Eryma and the new combination Eryma antiquum (Birshtein, 1958) is herein proposed.

Garassino and Krobicki (2002) erected the new genus Galicia with Galicia marianae (Oxfordian; southern Poland) as the type species. Most of the authors assigned this genus to the family Erymidae (Garassino and Krobicki, 2002; Schweitzer et al., 2010; Karasawa et al., 2013; Feldmann et al., 2015) while others included it in the family Clytiopsidae because of the absence of intercalated plate (Feldmann et al., 2012). Our review of the holotype indicates a carapace shape and a groove pattern typical of an Erymidae (subcylindrical carapace, deep cervical groove, gastro-orbital groove present, postcervical and branchiocardiac grooves almost parallel). Moreover, the carapace groove pattern exhibits the junction between the postcervical and the branchiocardiac grooves which is diagnostic of the genus Eryma (Fig. 2G-H). Hence, we consider Galicia to be a junior synonym of Eryma.

In addition, Galicia marianae exhibits a carapace with the following morphological characters: a wide branchial region, a well-marked gastro-orbital groove, subparallel postcervical and branchiocardiac grooves, slightly concave forward, a short branch extends the postcervical groove under its junction with branchiocardiac groove, a slightly inflated $\omega$ area and a flat $\chi$ area, an ornamentation made of fine tubercles. The carapace groove pattern and ornamentation are very similar to those of the well-known Eryma ventrosum (Meyer, 1835) from the Terrain à Chailles Formation (Oxfordian, Haute-Saône, France) (Meyer, 1840b; Bronn, 1851-1852; Étallon, 1859; Van Straelen, 1925; Charbonnier et al., 2012) (Fig. 2C-D). Hence, we consider G. marianae to be a junior synonym of E. ventrosum.

\section{Stratigraphic implications}

Until now, Eryma extended from Sinemurian (Early Jurassic), with E. meyeri Garassino, 1996, to Albian (Early Cretaceous), with E. vocontii Devillez et al., 2016.

However, our examination of the holotype MSNM 17606 of E. meyeri (Osteno, Italy) reveals morphological characters diagnostic of Palaeastacus Bell, 1850: postcervical groove not joined medially to branchiocardiac groove but joined ventrally to hepatic groove, short and stout P1 chelae covered by spines (Fig. 3A-B). Thus, we propose the new combination: Palaeastacus meyeri (Garassino, 1996). Our review of the holotype MSNM il3517 of Pustulina sinemuriana Garassino, 1996, from the same locality (Osteno, Italy) reveals morphological characters diagnostic of Eryma: postcervical and branchiocardiac grooves joined medially, elongate P1 chelae (Fig. 3C-D). Thus, we propose the new combination: Eryma sinemuriana (Garassino, 1996).

Most of the described species of Eryma occurs in Jurassic (Fig. 2A-D, 2G-H, 3C-D) while only four species occurs in Early Cretaceous (Devillez et al., 2016): Eryma glaessneri (Van Straelen, 1936) and Eryma sulcatum Harbort, 1905 in Hauterivian (Fig. 3I-L), Eryma nippon Karasawa et al., 2008 in Barremian and E. vocontii Devillez et al., 2016, in Albian (Fig. 3E-H). Other Eryma species found in Late Cretaceous deposits were described from North America (E. americanum Rathbun, 1923, E. flectum Rathbun, 1926, E. stantoni Rathbun, 1935) and Lebanon (E. cretaceum Roger, 1946). After careful examination of the figures presented by Rathbun (1923, 1926, 1935) and according to Förster (1966: 125), we consider that the American species, only represented by fragments of specimens, are not representatives of Erymidae. As for the Lebanese species, we follow Charbonnier et al. (in press) with the placement in Pustulina Quenstedt, 1857.

Addition of Protoclytiopsis Birshtein, 1958 to the synonymy of Eryma extends the stratigraphic range of the genus Eryma to the Late Permian (Changhsingian). Previously, Bachmayer and Malzahn (1983) had doubtfully assigned to Erymastacus a poorly preserved P1 chela from the Late Permian of Germany: Erymastacus (?) hoerstgenensis. As Schweitzer et al. (2010) regarded Erymastacus as synonymous with Eryma, they listed the species within representatives of Eryma. Later, Karasawa et al. (2013) removed the species from Erymidae because of its angular propodus and the shape of its fingers. Examination of the figure of the holotype of E. hoerstgenensis leads us to support the opinion of Karasawa et al. (2013).

Thus, Eryma antiquum (Birshtein, 1958) nov. comb., is the only erymid lobster reported in the Paleozoic and the oldest known representative of Eryma and Erymidae.

Finally, it is worth pointing out that the gap of almost 50 million years without reported Eryma between its two oldest representatives $(E$. antiquum nov. comb. from the Changhsingian and $E$. sinemuriana nov. comb.from the Sinemurian) shows the lack of fossils in the record of Eryma during the Trias. 

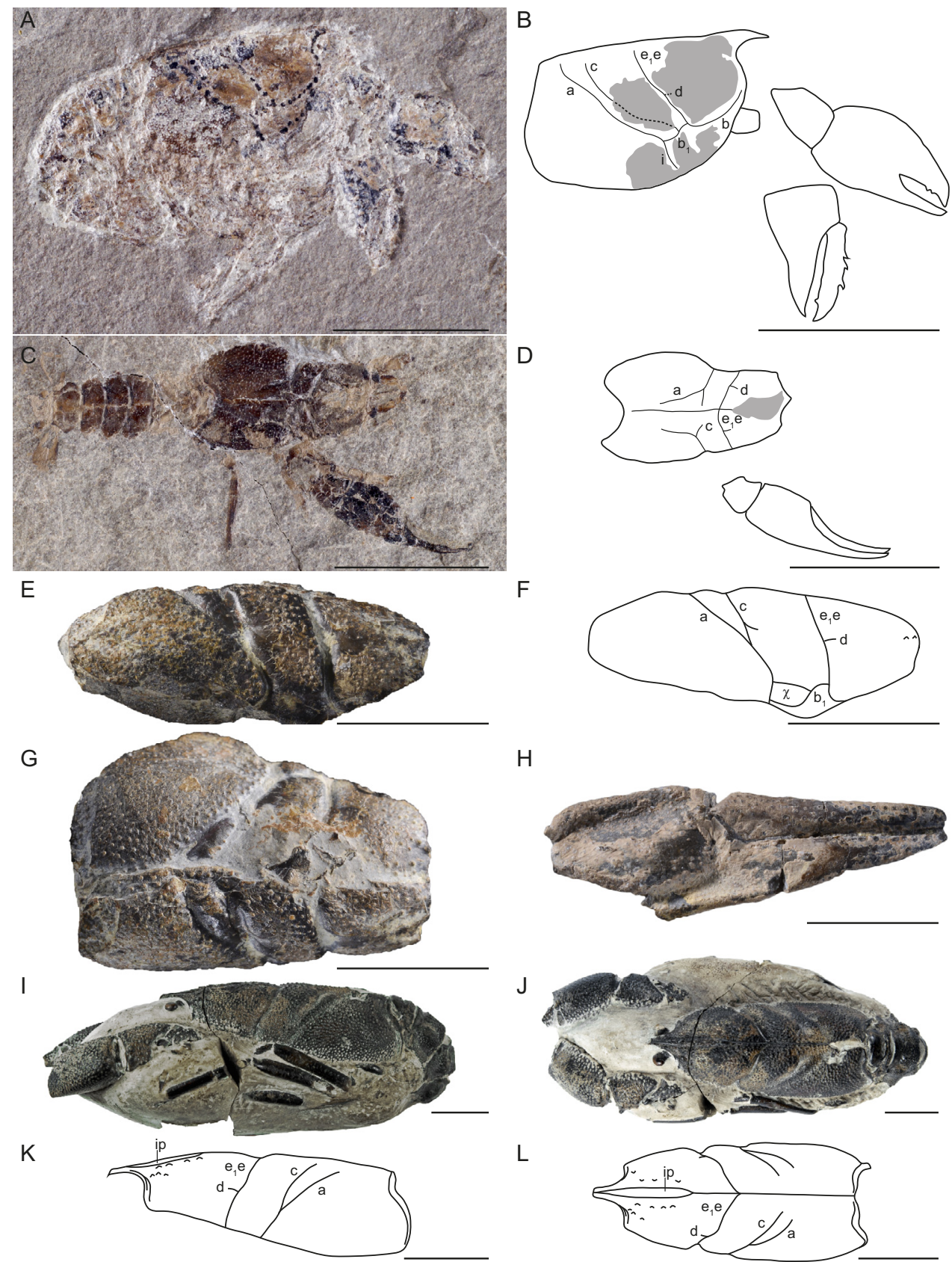

$\mathrm{F}$
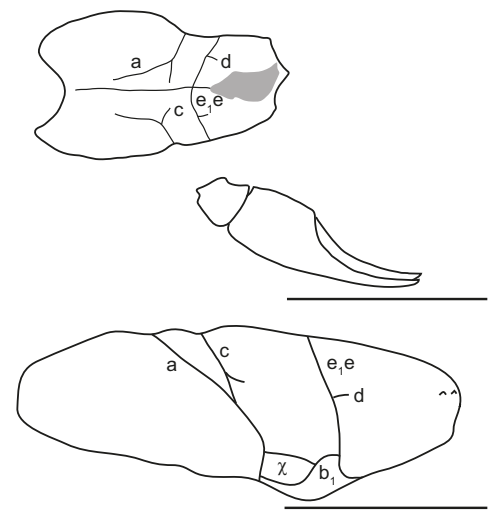

$\mathrm{H}$

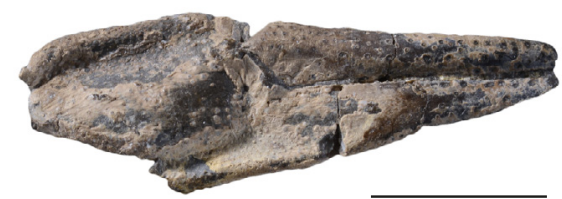

$\mathrm{J}$

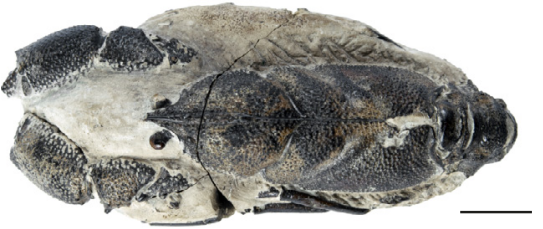

L

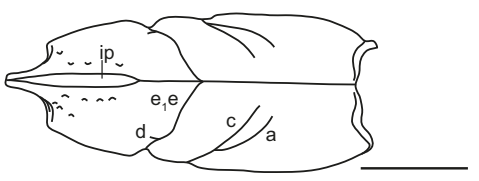

Fig. 3. Erymid lobsters from Early Jurassic and Early Cretaceous. A-B, holotype MSNM i7606 of Palaeastacus meyeri (Garassino, 1996), originally described as Eryma, from the Sinemurian of Osteno, Italy: whole specimen (A) and line drawing of the carapace and of the P1 chelae (B); C-D, holotype MSNM il3517 of Eryma sinemuriana (Garassino, 1996), originally described as Pustulina, from the Sinemurian of Osteno, Italy: whole specimen (C) and line drawing of the carapace and of the P1 chela (D); E-G, holotype MNHN.F.A57457 (Clément coll.) of Eryma vocontii Devillez et al., 2016, from the Albian of Rosans, France: carapace in lateral view (E), line drawing $(\mathrm{F})$ and carapace in dorsal view (G); $H$, paratype MNHN.F.A57458 (Clément coll.) of Eryma vocontii from the Albian of Rosans, France; I-L, Neotype SM B11437 of Eryma sulcatum Harbort, 1905 from the Hauterivian of Speeton, United Kingdom: specimen in lateral view (I), specimen in dorsal view (J), line drawing of the carapace in lateral view $(\mathrm{K})$ and line drawing of the carapace in dorsal view $(\mathrm{L})$. Scale bars $=10 \mathrm{~mm}$. Abbreviations: $a$ : branchiocardiac groove; b: antennal groove; $b_{1}$ : hepatic groove; c: postcervical groove; d: gastro-orbital groove; $\mathrm{e}_{1} \mathrm{e}$ : cervical groove; i: inferior groove; ip: intercalated plate; $\chi$ : attachment site of adductor testis muscle. Photographs: A. Garassino (A, B), L. Cazes (E, F), J. Devillez (G, H). Line drawings: J. Devillez. 


\section{Conclusions}

A review of erymid genera leads us to consider Protoclytiopsis Birshtein, 1958, and Galicia Garassino and Krobicki, 2002, as junior synonyms of Eryma. Moreover, Galicia marianae Garassino and Krobicki, 2002, is herein considered to be a junior synonym of Eryma ventrosum (Meyer, 1835) on the basis of its carapace groove pattern and ornamentation. These additions into the synonymy of Eryma result in the extension of its stratigraphic range to Changhsingian (Late Permian). Thus, Eryma survived the Permian-Triassic mass extinction, commonly considered as the biggest of all major extinctions (Raup, 1979; Erwin, 1994; Stanley and Yang, 1994), with the occurrence of Enoploclytia gardnerae (Rathbun, 1935) in Mexican Paleocene deposits (Vega et al., 2007), it is worth noting that Erymidae also survived the Cretaceous-Paleogene mass extinction. However, E. gardnerae is the last occurrence of erymid lobsters in the fossil record so they are considered to be extinct. The presence of an intercalated plate, an exclusive character of Erymidae, was recognized by Schram and Dixon (2004) in members of the extant family Enoplometopidae (Saint Laurent, 1988). This observation leads us to question the link between Erymidae and Enoplometopidae.

Acknowledgments. We wish to thank Claire Mellish (Natural History Museum, London, United Kingdom), Fabienne Giraud-Guillot (Université Joseph Fournier - Institut Dolomieu, Grenoble, France), Liz Harper and Matt Riley (Sedgwyck Museum, Cambridge, United Kingdom) for the access to the collections of their respective institutions.

We are also grateful to A. Garassino (Museo di Storia Naturale di Milano, Italy), G. Schweigert (Staatliches Museum für Naturkunde, Stuttgart, Germany), F. Schram (University of Washington Seattle, Seattle, USA) and R. Feldmann (Kent State University, Kent, USA) who provided the pictures the type material of the erymid lobsters from Italy, Germany and Russia. We also really thank Jean-Michel Pacaud (MNHN, Paris, France), for helping to solve some nomenclatural complications and Lilian Cazes (MNHN, Paris, France) for the photographs of some specimens.

Finally, we reiterate our thanks to Professor Rodney Feldmann for his constructive comments which greatly improved our original manuscript.

This paper is a contribution to the UMR 7207 CR2P, CNRSMNHN-UPMC and to the "Département Histoire de la Terre" (Muséum national d'Histoire naturelle, Paris).

\section{Abbreviations}

GPANM

KSGR

MNHN.F

MSNM

NHMUK
Naturhistorisches Museum, Wien (Austria)

Department of Stratigraphy and regional geology of the University of mining and metallurgy, Kraków (Poland)

Muséum national d'Histoire naturelle, Paris (France)

Museo di Storia Naturale di Milano (Italy)

Natural History Museum, London (United Kingdom)
OSUG

PIN

SM

$\omega$

$\chi$

P1-P3

\section{References}

Aguirre-Urreta MB. 1989. The Cretaceous decapod Crustacea of Argentina and the Antarctic Peninsula. Palaeontology 32(3): 499-552.

Aguirre-Urreta MB, Ramos VA. 1981. Crustaceos Decapodos del Cretacico Inferior de la Cuenca Austral, Provincia de Santa Cruz, Argentina. Comité Sudamericano del Jurásico y Cretácico: Cuencas sedimentarias del Jurásico y Cretácico de América del Sur 2: 599-623.

Amati L, Feldmann RM, Zonneveld J-P. 2004. A new family of Triassic lobsters (Decapoda: Astacidea) from British Columbia and its phylogenetic contest. Journal of Paleontology 78(1): 150-158.

Bachmayer F, Malzahn E. 1983. Der erste Nachweis eines decapoden Krebses im niederrheinischen Kupferschiefer. Annalen des Naturhistorischen Museums in Wien 85(A): 99-106.

Bell T. 1850. Notes on the Crustacea of the Chalk Formation. In: Dixon F, ed. The Geology and Fossils of the Tertiary and Cretaceous Formations of Sussex. London: Longman, Brown, Green and Longmans, pp. 344-345.

Beurlen K. 1927. Zur Stammesgeschichte der jurassischen Macruren. Paläeontologische Zeitschrift 70: 115-278.

Beurlen K. 1928. Die Decapoden des Schwäbischen Jura mit Ausnahme der aus den oberjurassischen Plattenkalken stammenden. Palaeontographica 70: 115-278.

Beurlen K. 1933. Crustacea Decapoda aus den Tendaguru-schichten. Palaeontographica suppl. 7(2): 89-94.

Birshtein JA. 1956. Desyatinogie rakobrznye paleogena Fergany. Byulleten'Moskovskogo Obshchestva ispytatelei prirody 61: 63-75.

Birshtein JA. 1958. Ein Vertreter der ältesten Ordo der Crustacea Decapoda Protoclitiopsis antiqua gen. nov. sp. nov. aus dem Permo West-Sibiriens. Doklady Akademii Nauk, SSSR 122: 477-480.

Bravi S, Garassino A, Bartiromo A, Audo D, Charbonnier S, Schweigert G, et al. 2014. Middle Jurassic Monte Fallano Plattenkalke (Campania, southern Italy): first report on terrestrial plants, decapod crustaceans and fishes. Neues Jahrbuch für Geologie und Paläontologie 272(1): 79-107.

Bronn HG. 1851-1852. Dritte Periode. Oolithen-gebirge. In: Bronn HG, Roemer F, eds. Lethaea Geognostica oder Abbildung und Beschreibung der für die Gebirgs-formationen bezeichendstein Versteinerungen, part. 4. Stuttgart: E. Schweitzerbart, 570 p.

Carpentier C, Breton G, Huault V, Lathuilière B. 2006. Crustacés décapodes du Kimméridgien de Bure (Lorraine, France). Geobios 39: 617-629.

Carter JE. 1886. On the Decapod Crustaceans of the Oxford Clay. The Quaterly Journal of the Geological Society of London 42: 542-559.

Charbonnier S. 2009. Le Lagerstätte de La Voulte un environnement bathyal au Jurassique. Mémoires du Muséum national d'Histoire naturelle 199: 272.

Charbonnier S, Vannier J, Hantzpergue P, Gaillard C. 2010. Ecological significance of the arthropod fauna from the Jurassic (Callovian) La Voulte Lagerstätte. Acta Palaeontologica Polonica 55(1): 111-132. 
Charbonnier S, Pérès D, Letenneur C. 2012. Exceptionally preserved crustaceans from the Oxfordian of eastern France (Terrain à Chailles Formation, Haute-Saône). Geodiversitas 34(3): 531-568.

Charbonnier S, Garassino A, Schweigert G, Simpson M. 2013. A worldwide review of fossil and extant glypheid and litogastrid lobsters (Crustacea, Decapoda, Glypheoidea). Mémoires $d u$ Muséum national d'Histoire naturelle 205: 304.

Charbonnier S, Garassino A, Schweigert G, Audo D, Fernandez S. 2014. New look at the lobster Eryma greppini, Oppel, 1861 (Crustacea, Decapoda, Erymidae) from the Middle Jurassic of France and Switzerland. Neues Jahrbuch für Geologie und Paläontologie 272(3): 331-339.

Charbonnier S, Audo D, Barriel V, Garassino A, Schweigert G, Simpson M. 2015. Phylogeny of fossil and extant glypheid and litogastrid lobsters (Crustacea, Decapoda) as revealed by morphological characters. Cladistics 31: 231-249.

Charbonnier S, Audo D, Garassino A, Hyžný M. Fossil Crustacea of Lebanon. Mémoires du Muséum national d'Histoire naturelle, in press.

Crônier C, Courville P. 2004. A rich and highly endemic decapod crustacean fauna from the Middle Jurassic of north-east France. Palaeontology 47(4): 999-1014.

De Grave S, Pontcheff ND, Ahyong ST, Chan T-Y, Crandall KA, Dworschak PC, et al. 2009. A classification of living and fossil genera of decapod crustaceans. The Raffles Bulletin of Zoology 21: $1-109$.

Devillez J, Charbonnier S, Hyžný M, Leroy L. 2016. Review of the Early Cretaceous erymid lobsters (Crustacea: Decapoda) from the Western Tethys. Geodiversitas 38: 4.

Erwin DH. 1994. The Permo-Triassic extinction. Nature 367: 231236.

Étallon A. 1859. Description des crustacés fossiles de la Haute-Saône et du Haut-Jura. Bulletin de la Société géologique de France 16: 169-205.

Étallon A. 1861. Notes sur les crustacés jurassiques du bassin du Jura. Mémoires de la Société de l'agriculture, des sciences et lettres de la Haute-Saône 9: 129-171.

Etter W. 2004. Decapod crustaceans from the Middle Jurassic Opalinus Clay of northern Switzerland, with comments on crustacean taphonomy. Eclogae Geologicae Helvetiae 97: 381-392.

Feldmann RM, Haggart JW. 2007. A new species of lobster (Astacidea, Erymidae) from the Smithers Formation (Middle Jurassic) of British Columbia, Canada. Canadian Journal of Earth Sciences 44: 1791-1796.

Feldmann RM, Titus AL. 2006. Eryma jungostrix n.sp. (Decapoda; Erymidae) from the Redwater Shale of the Stump Formation (Jurassic; Oxfordian) of Utah. Journal of Crustacean Biology 26 (1): 63-68.

Feldmann RM, Schweitzer CE, Shixue H, Qiyue Z, Changyoing Z, Tao X, et al. 2012. Macrurous Decapoda from the Luoping biota (Middle Triassic) of China. Journal of Paleontology 86(3): 425441.

Feldmann RM, Schweitzer CE, Karasawa H. 2015. Crustacea. In: Selden PA, ed. Treatise online, Part R (Revised), Arthropoda 4(1), Chapter 8I. Lawrence, Kansas: University of Kansas Press, pp. 1-28.

Ferry M. De. 1865. Note sur les crustacés et les spongiaires de la base de l'étage Bathonien des environs de Macon. Bulletin de la Société linnéenne de Normandie 9: 365-376.

Fischer JC. 2003. Invertébrés remarquables du Callovien inférieur de la Voulte-sur-Rhône (Ardèche, France). Annales de Paléontologie 89: 223-252.

Förster R. 1965. Dekapoden der Neuburger Bankkalke (MittelTithon) von Neuburg an der Donau. Mitteilungen der Bayerischen
Staatssammlung für Paläontologie und Historische Geologie 5: 137-149.

Förster R. 1966. Über die Erymiden, eine alte konservative Familie der mesozoischen Dekapoden. Palaeontographica A125(4-6): 61-175.

Förster R, Seyed-Emani K. 1982. First occurrence of Eryma bedelta (Quenstedt) (Crustacea, Decapoda) from the Aalenian of Iran. Mitteilungen der Bayerischen Staatssammlung für Paläontologie und Historische Geologie 22: 41-45.

Garassino A. 1994. The macruran decapod crustaceans of the Upper Cretaceous of Lebanon. Paleontologia Lombarda (nuova serie) 3 : $1-27$.

Garassino A. 1996. The family Erymidae Van Straelen, 1924 and the superfamily Glypheoidea Zittel, 1885 in the Sinemurian of Osteno in Lombardy (Crustacea, Decapoda). Atti della Società italiana di Scienze naturali e del Museo civico di Storia natural in Milano 135: 333-373.

Garassino A, Krobicki M. 2002. Galicia marianae n. gen., n. sp. (Crustacea, Decapoda, Astacidea) from the Oxfordian (Upper Jurassic) of the Southern Polish Uplands. Bulletin of the Mizunami Fossil Museum 29: 51-59.

Garassino A, Schweigert G. 2006. The Upper Jurassic Solnhofen decapod crustacean fauna: review of the types from old descriptions. Part I. Infraorders Astacidea, Thalassinidea and Palinura. Memorie della Società italiana di Scienze naturali e del Museo civico di Storia naturale di Milano 34(1): 1-64.

Glaessner MF. 1929. Crustacea Decapoda. In: Pompeckj JF, ed. Fossilium Catalogus, I: Animalia, Pars 41. Berlin: W. Junk, pp. 1-464.

Glaessner MF. 1969. Decapoda. In: Moore RC, ed. Treatise on Invertebrate Paleontology, Part R, Arthropoda 4(2). Lawrence, Kansas: Geological Society of America, Boulder, Colorado, and University of Kansas Press, pp. 399-533.

Harbort E. 1905. Die Fauna der Schaumburg-Lippeschen Kreidemulde. Abhandlungen der Preussischen Geologischen Landesanstalt, Neue Folge 45: 10-22.

Hée A. 1924. Catalogue critique des crustacés jurassiques du Calvados et de l'Orne. Bulletin de la Société linnéenne de Normandie 7(6): 126-157.

Hyžný M, Schlögl J, Charbonnier S, Schweigert G, Rulleau L, Gouttenoire M. 2015. Intraspecific variation and taphonomy of a new erymid lobster (Crustacea: Decapoda) from the Middle Jurassic of Belmont (Beaujolais, France). Geobios 48: 371-384.

Karasawa H, Ohara M, Kato H. 2008. New records for Crustacea from the Arida Formation (Lower Cretaceous, Barremian) of Japan. Boletín de la Sociedad Geológica Mexicana 60(1): 101-110.

Karasawa H, Schweitzer CE, Feldmann RM. 2013. Phylogeny and Systematics of extant and extinct lobsters. Journal of Crustacean Biology 33(1): 78-123.

Kato H, Takahashi T, Taira M. 2010. Late Jurassic decapod crustaceans from Northeast Japan. Palaeontology 53(4): 761-770.

Krause HPG. 1891. Die Decapoden des norddeutschen Jura. Zeitschrift der Deutschen geologischen Gesellschaft 43: 171-225.

Lahusen J. 1894. Über die russischen Krebsreste aus den jurassischen Ablagerungen und derunteren Wolgastufe. Verhandlungen der Russischen Kaiserlichen Mineralogischen Gesellschaft 31(2): 313-324.

Latreille PA. 1802. Histoire Naturelle, Générale et Particulière des Crustacés et des Insectes. Tome 3. Paris:F. Dufart, 468 p.

Martill DM. 1991. Other invertebrates. In: Martill DM, Hudson JD, eds. Fossils of the Oxford clay. Dorchester: H. Ling, 285 p.

M'Coy F. 1849. On the classification of some British Fossil Crustacea, with Notices of new Forms in the University Collection 
at Cambridge. Annals and Magazine of Natural History, including Zoology, Botany, and Geology 4(2): 330-335.

Méchin A. 1901. Sur quelques formes nouvelles du genre Eryma (Astacomorpha fossiles) du Jurassique de Lorraine. Bulletin des Séances de la Société des Sciences de Nancy 2(3): 73-84.

Mertens H. 1833. Beobachtungen und Untersuchungen über die Beroëartigen Akalephen. Mémoires de l'Académie impériale des sciences de St. Pétersbourg 2(6): 479-543.

Meyer H. von. 1835. Briefliche Mittheilungen. Neues Jahrbuch für Mineralogie, Geognosie, Geologie und Petrefactenkunde 328-329.

Meyer H. von. 1840a. Briefliche Mittheilungen. Neues Jahrbuch für Mineralogie, Geognosie, Geologie und Petrefactenkunde 576-587.

Meyer H. von. 1840b. Neue Gattungen fossiler Krebse aus Gebilden vom bunten Sandstein bis in die Kreide. E. Stuttgart: Schweizerbart'sche Verlagshandlung, $28 \mathrm{p}$.

Münster G. 1839. Decapoda Macrura. Abbildung und Beschreibung der Fossilen Langschwänzigen Krebse in den Kalkschiefern von Bayern. Beiträge zur Petrefaktenkunde 2: 1-88.

Oppel A. 1861. Die Arten der Gattungen Eryma, Pseudastacus, Magila und Etallonia. Jahreshefte des Vereins für Vaterländische Naturkunde in Württemberg 17: 355-361.

Oppel A. 1862. Ueber jurassische Crustaceen (Decapoda macrura). Palaeontologische Mittheilungen aus dem Museum des koeniglich Bayerischen Staates 1: 1-120.

Quenstedt FA. 1856-1857. Der Jura. H. Tübingen: Laupp, 842 p.

Rathbun MJ. 1923. Decapod Crustaceans from the Upper Cretaceous of North Carolina. North Carolina Geological and Economic Survey 5: 403-408.

Rathbun MJ. 1926. Arthropoda. In: Wade B, ed. The Fauna of the Ripley Formation on Coon Creek, Tennessee. Professional Paper 137: 184-191.

Rathbun MJ. 1935. Fossil Crustacea of the Atlantic and Gulf Coastal Plain. Geological Society of America Special Papers 2: 1-160.

Raup DM. 1979. Size of the Permo-Triassic Bottleneck and its evolutionary implications. Science 206: 217-218.

Roger J. 1946. Les invertébrés des couches à poisons du Crétacé supérieur du Liban. Mémoires de la Société Géologique de France 51: 1-92.

Saint Laurent M. de. 1988. Enoplometopoidea, nouvelle superfamille de crustacés décapodes Astacidea. Comptes rendus de l'Académie des sciences 307(3): 59-62.

Schlotheim EF. von. 1822. Beiträge zur näheren Bestimmung der versteinerten und fossilen Krebsarten. Nachträge zur Petrefaktenkunde, Becker, Gotha 17-37.

Schram FR, Dixon CJ. 2004. Decapod phylogeny: addition of fossil evidence to a robust morphological cladistics data set. Bulletin of the Mizunami Fossil Museum 31: 1-19.

Schweigert G. 2013. A new record of the enigmatic lobster genus Stenodactylina Beurlen, 1928 (Crustacea: Decapoda: Erymidae) from the Middle Jurassic of south-western Germany. Paläontologische Zeitschrift 87: 409-413.
Schweigert G, Garassino A. 2003. New studies of decapod crustaceans from the Upper Jurassic lithographic limestones of southern Germany. Contributions to Zoology 72: 173-179.

Schweigert G, Dietl G, Röper M. 2000. Die Panzerkrebse des Familie Erymidae Van Straelen (Crustacea, Decapoda) aus dem Nusplinger Plattenkalk (Ober-Kimmeridgium, Schwäbische Alb) im Vergleich mit fränkischen Vorkommen. Stuttgarter Beiträge zur Naturkunde B 285: 1-25.

Schweitzer CE, Feldmann RM, Iuliana L. 2009. Fossil Crustacea (excluding Cirripedia and Ostracoda) in the University of Bucharest Collections, Romania, including two new species. Bulletin of the Mizunami Fossil Museum 35: 1-14.

Schweitzer CE, Feldmann RM, Garassino A, Karasawa H, Schweigert G. 2010. Systematic list of fossil decapod crustacean species. Crustaceana Monographs 10: 1-222.

Secrétan S. 1964. Les Crustacés décapodes du Jurassique supérieur et du Crétacé de Madagascar. Mémoires du Muséum national d'Histoire naturelle, Nouvelle série, Série C, Sciences de la Terre 14: 1-226.

Secrétan S. 1984. Présence d'Eryma bedelta (Crustacea Decapoda) dans le Bajocien du Maroc oriental. Geobios 17(4): 515-518.

Stanley SM, Yang X. 1994. A double mass extinction at the end of the Paleozoic Era. Science 266: 1340-1344.

Taylor BJ. 1979. Macrurous Decapoda from the Lower Cretaceous of South-Eastern Alexander Island. British Antarctic Survey Scientific Reports 81: 1-39.

Van Straelen V. 1920. Sur des crustacés du Jurassique de la Nièvre. Bulletin de la Société belge de géologie, de paléontologie et d'hydrologie 30: 139-142.

Van Straelen V. 1925. Contribution à l'étude des crustacés décapodes de la période jurassique. Mémoires de la Classe des Sciences de l'Académie royale de Belgique 7: 1-462.

Van Straelen V. 1936. Crustacés décapodes nouveaux ou peu connus de l'époque crétacique. Bulletin du Musée royal d'Histoire naturelle de Belgique 12(45): 1-50.

Vega FJ, Torrey N, Fraaye RHB, Espinosa B. 2007. Paleocene decapod crustacea from the Rancho Nuevo Formation (Parras Basin-difunta Group), Northeastern Mexico. Journal of Paleontology 6(81): 1432-1441.

Wahle RA, Thsudy D, Cobb JS, Factor J, Jaini M. 2012. Infraorder Astacidea Latreille, 1802 p. The Marine Clawed Lobsters. In: Schram FR, von Vaupel Klein JC, Charmantier-Daures M, Forest J, eds. Treatise of Zoology - Anatomy, Taxonomy, Biology - The Crustacea, Volume 9, Part B, Eucarida, Astacidea P.P. (Enoplometopoidea, Nephropoidea), Glypheidea, Axiidea, Gebiidea, and Anomura. Leiden and Boston: Brill, pp. 3-108.

Woods H. 1925-1931. A Monograph of the Fossil Macrurous Crustacea of England. London: The Palaeontographical Society, pp. 1-122.

Zittel KA. von. 1885. Handbuch der Palaeontologie 1 (2) (Arthropoda, Decapoda). R. Oldenbourg, Münich and Leipzig 523-721.

Cite this article as: Devillez J, Charbonnier S. 2017. The genus Eryma Meyer, 1840 (Crustacea: Decapoda: Erymidae): new synonyms, systematic and stratigraphic implications, Bull. Soc. géol. Fr. 188: 15. 